\title{
The Relationship between Leadership Practices and Organizational Performance
}

\author{
Anas Y. Alhadid ${ }^{1}$ \\ ${ }^{1}$ Department of Marketing, Applied Science Private University, Amman, Jordan \\ Correspondence: Anas Y. Alhadid, Assistant Professor in the Department of Marketing, Applied Science Private \\ University, Amman, Jordan. Tel: 962-79-976-4241.
}

Received: March 29, 2016

Accepted: April 11, 2016

Online Published: April 22, 2016

doi:10.5430/ijba.v7n3p57

URL: http://dx.doi.org/10.5430/ijba.v7n3p57

\begin{abstract}
The aim of the study is to inspect the effect of leadership - in both its transactional and transformational styles - as a mediator variable on the relation between leadership practices and organizational performance. The survey was established and allocated for upper and middle administrative employees. Researchers utilized the multiple recession and hierarchy recession inquiry to calculate the impact of leadership practices on organizational performance and leadership styles - transactional and transformational.

The present study of the relation between leadership practices and organizational performance had a positive effect, in addition to the interaction between leadership practices and styles - transactional and transformational.
\end{abstract}

Keywords: leadership practices, performance, organization, Jordan

\section{Introduction}

Leadership can be the key factor influencing the success of strategies and creating competitive advantages in a dynamic environment. Leadership is also considered a key utility of administration, which could help with achieving the effectiveness and efficiencies of an organizational performance - both financial and nonfinancial. Leadership could be defined as, "the relation between an individual and a group that is constructed round mutual interests, in which the group act in a fashion set to them by the leader." (Shastri, Shashi Mishra and Sinha, 2010) Leadership could be affected by the behaviour of the supporters by using specific practices as Team Building, Supporting, Mentoring, Rewarding, and Consulting. Likewise, leadership transactional and transformational styles are considered as aspects which have a major impact on the performance of organizations. (Wang et al., 2005)

On the other hand, organizational performance, both financial and nonfinancial, is an important indicator for organization success; wherein our study we did focus on the banking sector in Jordan.

\section{Theoretical Background}

Leadership Style is divided into (2) main styles, which are the Transactional and the Transformational. The transactional style is used to motivate employees by using tangible rewards while the transformational style uses intangible rewards.

1. Transactional Leadership is the vibrant interchange between leaders and their supporters, where he/she inaugurates particular aims, observers programs, and classifies payments upon goal achievement. (Yukl, 1998)

2. Transformational Leadership is the procedure of pursuing cooperative aims throughout the reciprocated tapping of both leaders and supporters' motive bases in the direction of the anticipated change. (Burns, 1978)

Leadership Practices depending on the study done by Yukl (1989), there are (14) leadership practices which have been successively advanced into a broadly used procedure, otherwise known as "The Managerial Practices' Study," where it's included the following: Networking, Team Building, Supporting, Mentoring, Consulting, Delegating, Planning, and Clarifying. In our study, we only focused on some of them. 
1. Team Building is the procedure of altering a crowd that works together from a group of individuals performing correlated errands into a unified entity, whom exertions would return better results in oppose to the exertions performed by an individual on his/her own. (Mcshane and Von Glinow, 2003)

2. Supporting where it can be defined as the process of enhancing feeling expatriates may have toward their organizations to help to achieve great performance. (Guzzo et al. 1994)

3. Mentoring is the process of establishing personal growth and enhancement for advisors through a mutually dependent and awarding relationship. (Ragins, 2005)

4. Rewarding is the process of inducing employees to deliver high-quality services by encouraging them with monetary and non-monetary gifts. (Yava et al. 2003)

5. Consulting is the process by which guiding the employees to adjust their way of accomplishing the work. (Yukl, 1989)

Organizational Performance was discussed in many types of research, due to its significance in emerging organizations. It was first defined as, "a tool which is applied by assess organization success, and provide assets to internal and external investors," (Antony and Bhattachatyya, 2010) whereas Moullin (2007) defined it as "a measure which is used by organizations to accomplish efficiency, and bring about the value intended to the investors and clients. Where it consist of (2) aspects of a following:

1. Financial Performance, which can be achieved by eradicating pollution, and recycling waste resources. (Hart, 1997; Taylor, 1992) Green management can yield numerous opportunity to reduce cost, and eventually, increase revenue in (3) different ways (Better Entrée to Particular Markets; Distinguishing Products; and Selling Pollution-Control Technology). (Ambec and Lanoie, 2008)

2. Non-Financial Performance which is related to genetically altering plants in order to lessen their air discharges, emission and solid wastes, as well as the consumption of contaminated materials. Furthermore, it reduces the frequency at which environmental incidents occur, and improves the readiness to act during environmental situations. It is similarly related to adjusting plants so as to harvest and provide supplies for the clients, in which there is an upsurge in the total of goods delivered on time, quality and line, and a diminution in inventory levels, and scrape rates. (Zhu et al., 2008)

\section{Research Model}

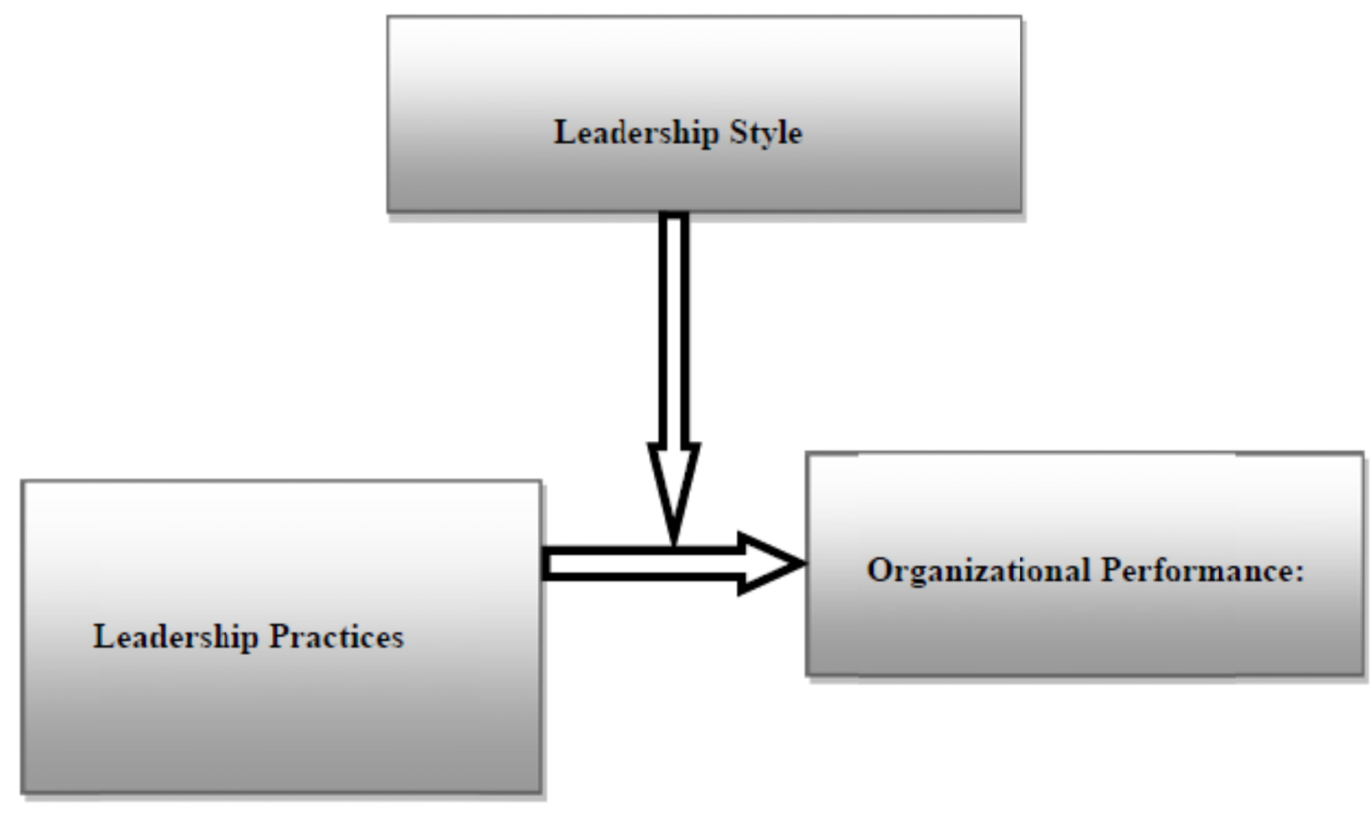




\section{Methodology}

\subsection{Population}

This study was embodied by Commercial Banks in Jordan, which involved (13) Banks. Our sample only included (4) of these Banks (Arab Bank; Housing Bank; Jordan Kuwait Bank; and Cairo Amman Bank); the number of distributed surveys was (143). The unit sample was consistent of upper and middle administrative employees.

\subsection{Collection Data Tool}

The study relies on surveys as the chief tool, which are consistent of (4) parts. The first one collected demographic data. The second enclosed Leadership Practices (Team Building, Supporting, Mentoring, Rewarding, and Consulting) via (20) questions employed from former studies, while the third enclosed the (2) dimensions of organizational performance - Financial and Non-Financial Performance - via (10) questions, also employed from former studies. The fourth enclosed the Leadership Styles - Transactional and Transformational Leadership Styles - via (8) questions employed from. All questions were answered based on the 5-Likert scale.

\subsection{Data Analysis}

Descriptive Statistics and Correlation Matrix for all variables were denoted in Table 1. Multi Regression Results was used to assess the outcome of Leadership Practices on Organizational Performance in Table 2 while both Transactional and Transformational Leadership Style as a Moderate Variable between Leadership Practices and Organizational Performance used Hierarchy regression analysis in Tables 3 and 4, respectively.

Table 1. Descriptive statistics and correlation matrix

\begin{tabular}{ccccccccccc}
\hline Variables & LS & TRL & TL & LP & TB & S & M & R & C & OP \\
\hline Means & 4.321 & 5.221 & 3.225 & 4.241 & 3.665 & 4.578 & 3.251 & 4.207 & 4.025 & $\mathbf{4 . 0 0 2}$ \\
\hline SD & .541 & .421 & .542 & .425 & .584 & .625 & .745 & .558 & .687 & .745 \\
\hline LS & 1 & & & & & & & & & \\
TRL & $.558^{* *}$ & 1 & & & & & & & & \\
TL & $.452^{* *}$ & $.658^{* *}$ & 1 & & & & & & & \\
LP & $.651^{* *}$ & $.487^{* *}$ & $.625^{* *}$ & 1 & & & & & & \\
TB & $.447^{* *}$ & $.562^{* *}$ & $.741^{* *}$ & $.685^{* *}$ & 1 & & & & & \\
S & $.554^{* *}$ & $.785^{* *}$ & $.854^{* *}$ & $.414^{* *}$ & $.587^{* *}$ & 1 & 1 & & & \\
M & $.447^{* *}$ & $.524^{* *}$ & $.587^{* *}$ & $.433^{* *}$ & $.765^{* *}$ & $.587^{* *}$ & 1 & & & \\
\hline $\mathbf{R}$ & $.458^{* *}$ & $.521^{* *}$ & $.625^{* *}$ & $.554^{* *}$ & $.785^{* *}$ & $.624^{* *}$ & $.687^{* *}$ & 1 & & \\
$\mathbf{C}$ & $.541^{* *}$ & $.541^{* *}$ & $.458^{* *}$ & $.456^{* *}$ & $.658^{* *}$ & $.618^{* *}$ & $.452^{* *}$ & $.365^{* *}$ & 1 & \\
$\mathbf{O P}$ & $.458^{* *}$ & $.471^{* *}$ & $.621^{* *}$ & $.460^{* *}$ & $.551^{* *}$ & $.623^{* *}$ & $.681^{* *}$ & $.350^{* *}$ & $.655^{* *}$ & $\mathbf{1}$ \\
\hline & & & & $* * * \mathbf{P}<\mathbf{0 . 0 5}$ & & & & & \\
\hline
\end{tabular}

\subsection{Hypothesis Testing}

Table 2. Multi regression results

\begin{tabular}{cccc}
\hline Variables & $\boldsymbol{\beta}$ & $\mathbf{T}$ & SIG.* $^{*}$ \\
\hline Team Building & 0.336 & 1.073 & $0.000^{*}$ \\
Supporting & 0.325 & 1.397 & $0.002 *$ \\
Mentoring & 0.065 & 2.54 & 0.096 \\
Rewarding & 0.358 & 1.005 & $0.001 *$ \\
Consulting & 0.402 & 2.22 & $0.000 *$ \\
$\left.\mathbf{( R}^{2}=\mathbf{0 . 3 2 5} ; \mathbf{F}=\mathbf{1 0 . 3 5 6}\right)$ & $* \mathbf{P} \leq \mathbf{0 . 0 5}$ \\
\hline
\end{tabular}


Table 3. Hierarchy regression results

\begin{tabular}{cccc}
\hline Variables & $\boldsymbol{\beta}$ & $\mathbf{T}$ & SIG.* \\
\hline Leadership Practices & 0.414 & 3.025 & $0.000^{*}$ \\
Interaction between Leadership Practices and Transactional Leadership & 0.389 & 2.541 & $0.001 *$ \\
$\left(\mathbf{R}^{\mathbf{2}}=\mathbf{0 . 2 6 4} ; \mathbf{F}=\mathbf{1 1 . 2 3 5} ; \mathbf{R}^{\mathbf{2}} \mathbf{C h a n g e}=\mathbf{0 . 1 6 4 )}\right) \mathbf{P} \leq \mathbf{0 . 0 5}$ & & \\
\hline
\end{tabular}

Table 4. Hierarchy regression results

\begin{tabular}{cccc}
\hline Variables & $\boldsymbol{\beta}$ & $\mathbf{T}$ & SIG.* \\
\hline Leadership Practices & 0.414 & 3.025 & $0.000^{*}$ \\
Interaction between Leadership Practices and Transformational Leadership & 0.296 & 3.001 & $0.002 *$ \\
$\left(\mathbf{R}^{\mathbf{2}}=\mathbf{0 . 4 0 2} ; \mathbf{F}=\mathbf{1 1 . 2 3 5} ; \mathbf{R}^{\mathbf{2}} \mathbf{C h a n g e}=\mathbf{0 . 1 7 5 )}\right) \mathbf{P} \leq \mathbf{0 . 0 5}$ & & & \\
\hline
\end{tabular}

\section{Conclusion}

The study deals with leadership practices variable through (5) dimensions: Team Building, Supporting, Mentoring, Rewarding, and Consulting; while organizational performance consists of (2) dimensions: financial performance, and non-financial performance. While the leadership styles dealt with the study through (2) dimensions: transactional and transformational leadership style.

The main aim of the study is to measure the effect of Leadership practices in the Jordanian commercial banks in enhancing organizational performance whereby through testing the team building and supporting, rewarding and consulting is most affecting on organizational performance and there is no effect from mentoring. The interaction between leadership practices and transactional leadership leverage the organizational performance, $\left(\mathrm{R}^{2}\right.$ Change $=$ 0.175 , and $\beta=0.296$ ) and the interaction between leadership practice and transformational leadership also leverage the organizational performance. $\left(\mathrm{R}^{2}\right.$ Change $=0.164$, and $\left.\beta=0.389\right)$

\section{References}

Abo Yassin, N., \& Abood, N. (2013). The Effect of Ineffective Leadership on Individual and Organizational Performance in Jordanian Institutions. International Business Journal, 23(1), 68-84.

Avery, B. (2011). Sustainable Leadership Practices for Enhancing Business Resilience and Performance. Strategy and Leadership, 39(3), 5-15. http://dx.doi.org/1108/13683041074209

Burke, S., \& Collins, K. (2001). Gender Differences in Leadership Styles and Management Skills. Women in Management Review, 16(5), 244-256.

Cangemi, L., McQuade, F., Conner, M., \& Murphree. (2011). Successful Leadership Practices during Turbulent Times. Journal of Management Development, 30(1), 30-43.

Gadot, E. (2007). Leadership Style, Organizational Politics, and Employees' Performance: An Empirical Examination of Two Competing Models. Personal Review, 36(5), 661-683.

Goldman, E. (2012). Leadership Practices that Encourage Strategic Thinking. Journal of Strategy and Management, 5(1). http://dx.doi.org/10.1007/s10551-006-9025-5

Jogulu, U. (2010). Culturally-Linked Leadership Styles. Leadership and Organization Development Journal, 31(8), 705-719.

Jordanian Banks Reports. (2014). Association of Banks in Jordan. Retrieved April 8, 2014, from www.abj.org

Kathuria, P., \& Greenhaus. (2010). Leadership Practices, Competitive Priorities, and Manufacturing Group Performance. International Journal of Operations and Production Management, 30(10), 1080-1105. http://dx.doi.org/10.1108/02635571211264609

Limsila, K., \& Ogunlana, S. (2008). Performance and Leadership Outcome Correlates of Leadership Styles and Subordinate Commitment. Engineering, Construction and Architectural Management, 15(2), 164-184. 
Mendelson, M., Turner, N., \& Barling, J. (2011). Perceptions of the Presence and Effectiveness of High Involvement Work Systems and Their Relationship to Employee Attitudes: A Test of Competing Models. Personal Review, $40(1)$.

Ozcelik, H., Langton, N., \& Aldrich, H. (2008). Doing Well and Doing Good. Journal of Managerial Psychology, 23(2).

Randeree, K., \& Chaudhry, A. (2012). Leadership-Style, Satisfaction and Commitment. Engineering, Construction and Architectural Management, 19(1), 61-85. http://dx.doi.org/10.1108/095268071743327

Sabri, H. (2007). Jordanian Managers Leadership Styles in Comparison with the International Air Transport Association (IATA) and Prospects for Knowledge Management in Jordan. International Journal of Commerce and Management, 17(1/2), 56-72.

Svensson, G., \& Wood, G. (2006). Sustainable Components of Leadership Effectiveness Performance. Journal of Management Development, 25(6), 522-534.

Turner, R., Muller, R., \& Dulewicz, V. (2009). Comparing the Leadership Styles of Functional and Project Managers. International Journal of Managing Projects in Business, 2(2), 198-216. http://dx.doi.org/10.4236/ti.2013.43019 